\title{
BEZPIECZEŃSTWO SPOŁECZNO-EKONOMICZNE POLSKI Z PERSPEKTYWY CZYNNIKA DEMOGRAFICZNEGO
}

Bezpieczeństwo państwa jest jedną z najcenniejszych wartości. W drugiej połowie $\mathrm{XX}$ wieku, kiedy wzrosło natężenie współzależności w stosunkach międzynarodowych i przyspieszyły procesy globalizacji, bezpieczeństwo przestało być utożsamiane wyłącznie z wymiarem polityczno-militarnym.

Równie ważne dla bezpieczeństwa okazały się inne sfery działalności państwa, jak gospodarka, ekologia, kultura czy społeczeństwo. W każdej z tych dziedzin pojawiają się problemy, które mogą zagrozić bezpieczeństwu państwa. W Polsce jednym z takich problemów są bardzo niekorzystne zmiany demograficzne zachodzące w polskim społeczeństwie. Ich negatywne skutki będą odczuwalne już za ok. 20 lat i będą kształtowały bezpieczeństwo Polski, w jego wymiarze narodowym, regionalnym i międzynarodowym.

Bezpieczeństwo jest jedną z najbardziej chronionych i pożądanych wartości, zarówno przez jednostki, grupy społeczne, państwa, jak i system międzynarodowy. Jego rozumienie zmieniało się na przestrzeni wieków. Od „,politycznej stabilności”, , którą oznaczało w czasach starożytnego Rzymu do interpretacji znacznie rozszerzonej, obowiązującej współcześnie, która traktuje bezpieczeństwo jako stan pewności, spokoju, zabezpieczenia, braku zagrożenia oraz ochrony przed nim $^{2}$. Interpretacja bezpieczeństwa, chociaż zmienia się w zależności od specyfiki nauki wyznaczającej zakres badań, to zawsze rozpatrywana jest w kategoriach wartości, procesu i stanu ${ }^{3}$.

Naczelną wartością jest przetrwanie oznaczające trwałą egzystencję państwa, narodu czy jednostki. O tę wartość każdy z podmiotów musi stale zabiegać w zmieniającym się środowisku, zarówno wewnętrznym, jak i zewnętrznym. Bezpieczeństwo rozpatrywane jako proces wskazuje na podejmowanie różnorodnych działań w celu ograniczenia, bądź wyeliminowania zagrożeń, które stanowią przeszkodę w realizacji wszystkich celów istotnych dla poszczególnych podmiotów stosunków międzynarodowych. Dopełniającą rozumienie bezpieczeństwa jest kategoria stanu. Stan bezpieczeństwa danego podmiotu wskazuje na relację pomiędzy jego potencjałem obronnym a skalą zagrożeń. W każdym też przypadku bezpieczeństwo jest pojęciem dynamicz-

${ }^{1}$ K. A. Wojtaszczyk, Bezpieczeństwo państwa - konceptualizacja pojęć, w: Bezpieczeństwo państwa, red. K. A. Wojtaszczyk, A. Materska-Sosnowska, Warszawa 2009, s. 27.

2 R. Zięba, Instytucjonalizacja bezpieczeństwa europejskiego, Warszawa 2007, s. 27.

3 K. A. Wojtaszczyk, Bezpieczeństwo państwa - konceptualizacja pojęć, op. cit., s. 12. 
nym, zmieniającym swój zakres pojęciowy pod wpływem bodźców płynących z otaczającego świata ${ }^{4}$.

W drugiej połowie XX wieku przyspieszyły procesy internacjonalizacji i globalizacji w stosunkach międzynarodowych. Dokonująca się rewolucja naukowo-techniczna wymusiła wzrost współzależności pomiędzy podmiotami tychże stosunków. Zmienił się także charakter i źródła zagrożeń dla bezpieczeństwa państw. Powyższe zmiany wpłynęły w konsekwencji na zmianę tradycyjnie dotąd pojmowanego bezpieczeństwa.

Jak zauważa Adam Rotfeld: „...Na pojęcie bezpieczeństwa składają się dziś obok aspektów wojskowych i politycznych - czynniki gospodarcze i technologiczne, zasoby surowcowe oraz polityka w zakresie ekologii, demografii, spraw społecznych i humanitarnych"5.

Dodatkowym elementem definiującym bezpieczeństwo, wyróżnionym przez R. Ziębę, jest jakość życia rozumiana jako poziom życia oraz możliwości i perspektywy dalszego rozwoju ${ }^{6}$. Ta wieloaspektowość bezpieczeństwa pozwala na wyróżnienie wielu jego rodzajów w zależności od zastosowanego kryterium.

Tabela 1

Typologia bezpieczeństwa

\begin{tabular}{||l|l|l|l||}
\hline \multicolumn{4}{|c|}{ Kryterium } \\
\hline \multicolumn{1}{|c|}{ podmiotowe } & \multicolumn{1}{|c|}{ przedmiotowe } & \multicolumn{1}{|c|}{ przestrzenne } & \multicolumn{1}{c|}{ źródla zagrożeń } \\
\hline $\begin{array}{l}\text { międzynarodowe, } \\
\text { bezpieczeństwo państwa, } \\
\text { bezpieczeństwo jednostki }\end{array}$ & $\begin{array}{l}\text { polityczne, } \\
\text { militarne, } \\
\text { ekonomiczne, } \\
\text { ekologiczne, } \\
\text { socjalne, } \\
\text { informacyjne, } \\
\text { kulturowe, } \\
\text { inne }\end{array}$ & $\begin{array}{l}\text { lokalne, } \\
\text { subregionalne, } \\
\text { regionalne, } \\
\text { globalne }\end{array}$ & zewnętrzne \\
zewne,
\end{tabular}

Źródło: Bezpieczeństwo międzynarodowe po zimnej wojnie, red. R. Zięba, Warszawa 2008, s. 16.

Diametralna zmiana w sposobie współistnienia państw i narodów po II wojnie światowej wywołała z kolei zmiany charakteru oraz źródeł zagrożeń ich bezpieczeństwa.

Znaczenie tradycyjnego podejścia do bezpieczeństwa akcentującego czynnik militarny zmalało na rzecz działań prowadzących do ograniczenia zagrożeń pozamilitarnych takich jak:

- dysfunkcyjne mechanizmy gospodarcze i społeczne;

- konflikty społeczne, których władze państwowe nie są w stanie rozwiązać ${ }^{7}$;

- klęski żywiołowe;

- degradacja środowiska naturalnego;

4 Ibidem.

5 D. A. Rotfeld, Europejski system bezpieczeństwa in statu nascendi, Warszawa 1990, s. 38.

6 R. Zięba, Kategorie bezpieczeństwa w nauce o stosunkach międzynarodowych, w: Bezpieczeństwo narodowe i międzynarodowe u schyłku XX wieku, red. D. B. Bobrow, E. Haliżak, R. Zięba, Warszawa 1997, s. 6-7.

7 J.Zając, System bezpieczeństwa międzynarodowego, w: Bezpieczeństwo państwa, op. cit., s. 22. 
- migracje;

- przestępczość zorganizowana;

- terroryzm i cyberterroryzm;

- brak samowystarczalności energetycznej.

Wśród powyższych zagrożeń jednym z istotniejszych jest nieprawidłowo funkcjonujący system społeczno-gospodarczy państwa. W tym kontekście, biorąc pod uwagę przedmiotowe kryterium bezpieczeństwa można wyróżnić dwa jego rodzaje. Bezpieczeństwo ekonomiczne i bezpieczeństwo społeczne. Obie te sfery są ze sobą ściśle powiązane i od siebie zależne. Państwo stabilne i bezpieczne gospodarczo jest w stanie w większym zakresie zaspokajać podstawowe potrzeby swoich obywateli w postaci dostępu do edukacji, ochrony zdrowia czy infrastruktury ${ }^{8}$, co podnosi poziom bezpieczeństwa społecznego danego państwa.

Definicja bezpieczeństwa ekonomicznego państwa przedstawiona przez Z. Stachowiaka wskazuje, że ,jest to taki stan rozwoju krajowego systemu gospodarczego, który zapewnia wysoką sprawność jego funkcjonowania - przez należyte wykorzystanie wewnętrznych czynników rozwoju - oraz zdolność do skutecznego przeciwstawiania się zewnętrznym naciskom mogącym doprowadzić do zaburzeń rozwojowych" ". Wewnętrzne czynniki rozwoju to przede wszystkim dostęp do surowców naturalnych, wysoki poziom kapitału ludzkiego, oraz właściwa polityka gospodarcza ${ }^{10}$.

Bezpieczeństwo ekonomiczne jest jednym z trzech najważniejszych obok bezpieczeństwa militarnego i politycznego filarów bezpieczeństwa państwa. W jego skład wchodzą kwestie związane z bezpieczeństwem surowcowym, energetycznym, żywnościowym, finansowym, a także działania na rzecz niezakłóconego funkcjonowania gospodarki oraz utrzymania komparatywnej równowagi z gospodarkami innych państw $^{11}$.

O tym, że potencjał ekonomiczny państwa jest bardzo istotnym elementem jego potęgi i prestiżu na arenie międzynarodowej może świadczyć wypowiedź Lestera Browna, która została zamieszczona w wywiadzie jakiego udzielił w roku 1990. „Od 40 lat trzymamy się wojskowej definicji bezpieczeństwa narodowego, a bezpieczeństwo narodowe to problem ekonomiczny. Kto traci glebę i lasy - straci wkrótce zdolność produkcyjną ${ }^{12}$.

Bezpieczeństwo społeczne w najbardziej ogólnym rozumieniu oznacza taki stan rzeczy, w którym społeczeństwo jest wolne od zagrożeń i posiada zdolność swobodnego rozwoju. We współczesnym świecie zagrożenia społeczne występują bardzo intensywnie i wiążą się z takimi zjawiskami jak choćby: dezorganizacja, dysfunkcja, dolegliwość, niewydolność ${ }^{13}$. Zjawiska te są wyrazem permanentnego stanu społecz-

8 R. Włoch, Bezpieczeństwo ekonomiczne państwa, w: Bezpieczeństwo państwa, op. cit., s. 96.

9 Z. Stachowiak, Bezpieczeństwo ekonomiczne, w: Ekonomika obrony, red. W. Stankiewicz, Warszawa 1994, s. 180.

${ }^{10}$ R. Włoch, Bezpieczeństwo ekonomiczne państwa, op. cit., s. 96.

11 K. M. Księżopolski, Ekonomiczne zagrożenia bezpieczeństwa państw. Metody i środki przeciwdziałania, Warszawa 2004, s. 21.

${ }_{12}$ Raport o stanie świata - wywiad z Lesterem Brownem, „Ameryka”, Warszawa 1990, s. 11.

13 Bezpieczeństwo Spoleczne Rzeczypospolitej Polskiej, s. 63, http://www.adamkorcz.w.interia.pl/spol.pdf (15.09.2012). 
nej nierównowagi, który występuje w każdym społeczeństwie. Zmienny jest tylko jego zakres i natężenie. Można powiedzieć, że bezpieczeństwo społeczne państwa jest określane przez kwestie społeczne ${ }^{14}$, które są wyrazem asymetrycznych przekształceń w rozwoju gospodarczym.

Zagrożenia społeczne bezpieczeństwa państwa często są wynikiem błędnych decyzji podejmowanych w sferze gospodarki. Zarówno gospodarcza, jak i społeczna sfera są ze sobą ściśle powiązane i wzajemnie się przenikają, tworząc różnego rodzaju zagrożenia dla trwałego rozwoju państwa i dobrobytu jego obywateli.

Bardzo istotnym elementem bezpieczeństwa społeczno-ekonomicznego są przemiany ludnościowe, jakim podlegają wszystkie społeczeństwa. Zmiany liczby ludności, jej struktury, rozmieszczenia przestrzennego wywołują zawsze określone skutki - pozytywne bądź negatywne. Te negatywne generują swoiste zagrożenia, a walka z nimi jest coraz większym wyzwaniem dla polityków.

Polska także nie jest wolna od problemów powstających wskutek przemian demograficznych. Wydaje się że największym z nich jest zbyt wolno rosnąca liczba ludności kraju.

Tabela 2

Liczba ludności w Polsce wg spisów powszechnych w mln osób

\begin{tabular}{|c|c|c|c|c|c|c|c|}
\hline Rok & $\mathbf{1 9 5 0}$ & $\mathbf{1 9 6 0}$ & $\mathbf{1 9 7 0}$ & $\mathbf{1 9 7 8}$ & $\mathbf{1 9 8 8}$ & $\mathbf{2 0 0 2}$ & $\mathbf{2 0 1 1}$ \\
\hline & 25,0 & 29,8 & 32,6 & 35,0 & 37,9 & 38,2 & 38,5 \\
\hline
\end{tabular}

Źródło: Sytuacja Demograficzna Polski, Raport 2010-2011, GUS, Warszawa.

Podczas pierwszego powojennego spisu ludności przeprowadzonego w 1946 r. naliczono w Polsce 23,9 mln osób. Każdy kolejny spis (z roku 1950, 1960, 1970, 1978, 1988) pokazywał przyrost ludności na średnim poziomie $2,7 \mathrm{mln}$.

W roku 2002 liczba ludności wyniosła tylko 38,230 mln i w porównaniu do roku 1988 zwiększyła się tylko o ponad 300 tys. osób. Wyniki ostatniego spisu ludności, jaki odbył się w Polsce w 2011 r. ujawniły, że liczba mieszkańców Polski wzrosła jedynie o 270 tys. Do 38,5 mln osób. W przeciagu dziewięciu lat nastąpił wzrost tylko o 0,8 procent.

Na stopniowe pogarszanie się sytuacji ludnościowej Polski mają wpływ następujące czynniki:

1) pogorszenie się wskaźnika dzietności tzw. TFR (ang. Total Fertility Rate), którego wielkość z kolei określają: obniżenie skłonności do zawierania małżeństw, wzrost średniego wieku kobiet decydujących się na urodzenie pierwszego dziecka;

2) słaby stan zdrowia ludności Polski, a zwłaszcza nadumieralność mężczyzn;

3) gwałtowne starzenie się społeczeństwa;

4) zjawisko emigracji.

14 Kwestia społeczna to szczególnie dotkliwy, stojący w sprzeczności z najważniejszymi zasadami danej zbiorowości problem społeczny. Por.: Polityka Społeczna. Podręcznik akademicki, red. G. Firlik-Fesnak, M. Szylko-Skoczny, Warszawa 2007. 
Wskaźnik dzietności TFR jest syntetyczną miarą określającą poziom rozrodczości. Jest interpretowany, jako hipotetyczna średnia liczba urodzeń na jedną kobietę w ciąu jej życia. W Polsce wskaźnik ten na przestrzeni 65 lat drastycznie się obniżył. W latach 1946-1956 wynosił w niektórych regionach kraju nawet 4,0 (czworo dzieci na jedną kobietę).

Od 1956 r. liczba urodzonych dzieci zaczęła systematycznie maleć, aż w roku 1984 zanotowano trwały spadek płodności, który w 1989 r. doprowadził do spadku współczynnika dzietności do poziomu oznaczającego obszar zawężonej reprodukcji ludności, czyli poniżej wartości 2,15.

W roku 1990 wskaźnik TFR wynosił 2,03 i stale się obniżał aż w latach 2002, 2003 osiągnął wartość najniższą od 50 lat $-1,25$. W roku 2010 wartość TFR wynosiła 1,4 i na podobnym poziomie utrzymuje się od trzech lat ${ }^{16}$.

\section{Wykres 1. Współczynnik dzietności w Polsce w latach 1990-2011}

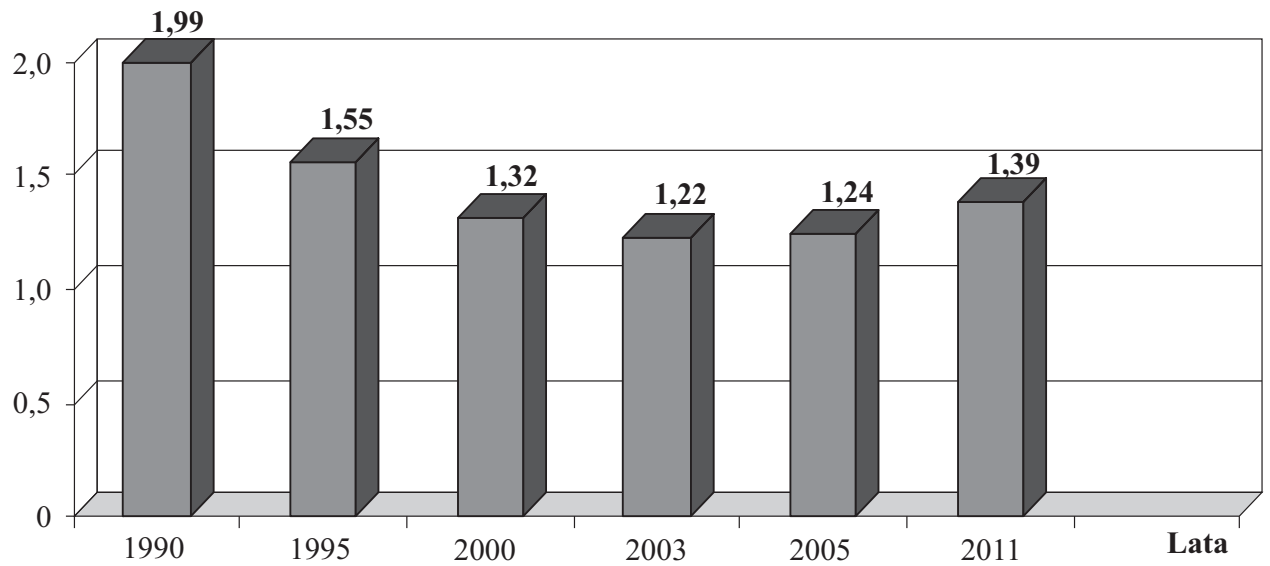

Źródło: Opracowanie własne na podstawie danych GUS.

Na obniżenie wskaźnika dzietności w Polsce duży wpływ ma obniżenie skłonności do zawierania małżeństw. Posiadanie dzieci i małżeństwo są w naszej kulturze jeszcze ciagle elementami nierozłącznymi. Obecnie w Polsce $80 \%$ dzieci przychodzi na świat w rodzinach tworzonych przez prawnie zawarte związki małżeńskie. Wg Departamentu Badań Demograficznych GUS zaznaczający się spadek skłonności do zawierania związków małżeńskich w konsekwencji przyniesie mniejszą liczbę urodzeń. W roku 2011 zostało zawartych 207 tys. małżeństw - to o 21 tys. mniej niż rok wcześniej. Tendencja zniżkowa utrzymuje się już 3 rok z rzędu. W długim okresie czasu ten niekorzystny trend może zostać odwrócony przez postępujące zmiany cywilizacyjne, które

15 M. Okólski, Przemiany ludnościowe we współczesnej Polsce w perspektywie minionego stulecia, w: Wymiary życia społecznego. Polska na przełomie XX i XXI wieku, red. M. Marody, Warszawa 2002, s. 53.

16 Podstawowe informacje o sytuacji demograficznej Polski w 2011 r., GUS, Departament Badań Demograficznych, Warszawa 2012. 
Wykres 2. Wskaźnik dzietności* w Polsce i wybranych krajach europejskich w 2009 roku

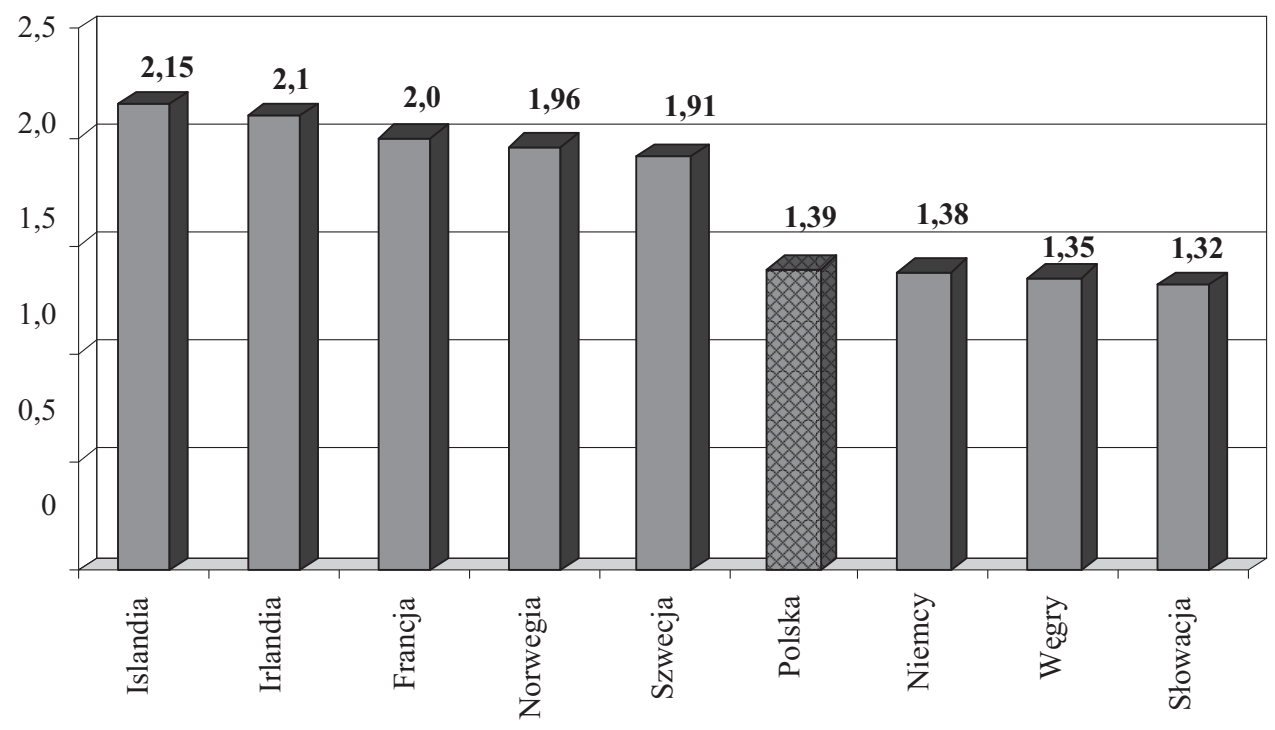

* Liczba dzieci jaką rodzi kobieta w wieku 15-49 lat.

Źródło: Eurostat, cyt. za: A. Gwiazda, Demograficzne wyzwania XXI wieku. Implikacje dla polityki międzynarodowej, Gdynia 2011, s. 58.

dają coraz większe przyzwolenie na posiadanie dzieci przez osoby pozostające w związkach nieformalnych. Już obecnie odsetek dzieci rodzących się w wolnych związkach wynosi $21 \%$. Na początku lat dziewięćdziesiątych XX wieku było to $6 \%$.

Drugi element wpływający na pogorszenie wskaźnika dzietności dotyczy wzrostu średniego wieku, w jakim kobiety wstępują w związek małżeński i rodzą swoje pierwsze dziecko. W latach 2000-2010 średni wiek kobiet będących matkami podniósł się z 26,1-28,6 lat. Przy czym w latach dziewięćdziesiątych ubiegłego wieku najczęściej matkami zostawały kobiety w wieku 20-24 lat. Obecnie najwięcej dzieci rodzą kobiety w przedziale wiekowym 25-29 i 30-34 lata. Coraz późniejsze macierzyństwo nawet przy niezmiennej dzietności oznacza, że pewna liczba dzieci nie przyjdzie nigdy na świat.

Dodatkowym czynnikiem wpływającym na coraz mniejszy przyrost naturalny w Polsce jest współczynnik umieralności. I choć w ciagu 20 lat zmniejszył się on o prawie $1 / 3$, to problemem pozostaje większa umieralność mężczyzn. Bardzo niepokojący jest także fakt wzraostu natężenia zgonów młodych mężczyzn. Na przestrzeni lat 1990-2010 wzrosło ono o 10\%, co oznacza, że obecnie śmierć mężczyzn z przedziału wiekowego 20-39 lat ma miejsce 3-krotnie częściej niż wśród kobiet.

Kolejnym czynnikiem powodującym zmniejszenie się liczby Polaków jest gwałtowne starzenie się społeczeństwa. Proces ten rozpoczął się już w końcu lat pięćdziesiątych XX wieku. Pomiędzy rokiem 1950-2010 udział ludzi w wieku powyżej 65 roku życia wzrósł w społeczeństwie z 5,3 do 13,6\%. Jednocześnie zmalał udział dzieci (0-14 lat) z 29,5 do $15,1 \%$. Zbiorowość ludzi starszych wciąż rośnie, a według prognoz GUS już w 2020 r. liczba osób po 65 roku życia zwiększy się z obecnych 5,185 mln do blisko 
7 milionów, natomiast w roku 2030 wiek senioralny osiagnie $22 \%$ Polaków $^{17}$. W tym samym czasie zmniejszy się liczba osób młodych (do 18 roku życia). Ich udział w całej populacji spadnie z obecnych 24,1 do $18,1 \%$.

Starzenie się społeczeństwa rodzi wiele problemów zarówno w sferze społecznej, jak i ekonomicznej. Wzrost udziału osób w wieku poprodukcyjnym powyżej 65 roku życia spowoduje większe obciążanie finansowe dla ludności w wieku produkcyjnym. Zależność tą pokazują tzw. współczynniki obciążenia demograficznego. W latach 2010-2012 utrzymuje się na takim samym poziomie i wynosi 19, co oznacza, ze na 100 Polaków w wieku produkcyjnym przypada 19 osób w wieku nieprodukcyjnym. Wg szacunków GUS, a także Eurostatu i Komisji Europejskiej zależność ta będzie coraz bardziej niekorzystna. W roku 2050 na 100 osób pracujących będzie przypadało nawet od 55 do 65 osób w wieku poprodukcyjnym ${ }^{18}$ (w zależności od instytucji szacującej). Za blisko 40 lat Polska będzie jednym z trzech najstarszych narodów w Unii Europejskiej.

Wykres 3. Współczynnik obciążenia demograficznego dla Polski

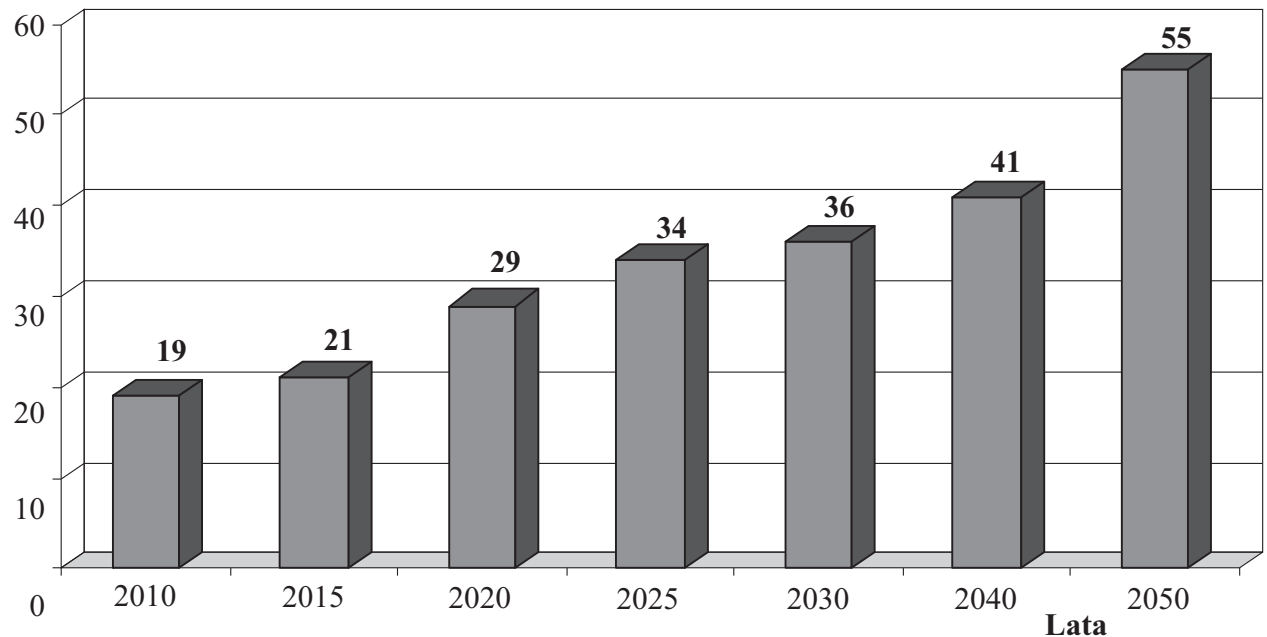

Źródło: GUS oraz prognozy Instytutu Badań Strukturalnych według „Dziennik Gazeta Prawna” 25.10.2010, s. A10; oraz A. Gwiazda, Demograficzne wyzwania XXI wieku. Implikacje dla polityki międzynarodowej, Gdynia 2011, s. 63.

Zwiększanie się liczby ludności starszej będzie miało swoje konsekwencje dla rynku pracy. Drastyczne skurczenie się zasobów siły roboczej spowoduje wzrost kosztów utrzymania pracowników, stworzy bariery rozwoju zarówno dla przedsiębiorstw nowych, jak i działających już na rynku, co z kolei wpłynie na spadek tempa wzrostu go-

17 A. Gwiazda, Demograficzne wyzwania XXI wieku. Implikacje dla polityki międzynarodowej, Gdynia 2011, s. 61.

18 GUS, Prognoza ludności na lata 2008-2035, Warszawa 2009, http://www.stat.gov.pl. 
spodarczego. Oddali to znacznie poprawę warunków życia w Polsce, bo jak zauważa Adam Gwiazda: ,Jeśli bowiem Polska rozwijać się będzie w rocznym tempie 3\% to dogoni bogate państwa Europy Zachodniej za około 75 lat. Jeśli tempo wzrostu w naszym kraju wynosić będzie $4 \%$ rocznie to okres ten skróci się do ok. 45 lat, a przy 5\% tempie wzrostu dogonimy kraje zachodnie dopiero za około 30-25 lat"19. Prognoza ta jest aktualna jeżeli kraje Europy Zachodniej będą osiagały zerowy przyrost PKB, w przeciwnym razie czas w jakim Polska osiagnie wyższy poziom rozwoju gospodarczego wydłuży się.

Jednocześnie wzrost dalszej przeciętnej długości życia spowoduje coraz większe obciążenie dla budżetu państwa $\mathrm{z}$ tytułu wypłacania rent i emerytur, a także funkcjonowania ośrodków nastawionych na świadczenie usług opiekuńczych czy związanych z opieką zdrowotną nad osobami starszymi.

Na powyższe kwestie nakłada się kolejny problem, który stanowi zagrożenie dla bezpieczeństwa społeczno-ekonomicznego państwa. Jest nim migracja. Polska wciąż pozostaje krajem migracji netto, co oznacza, że z kraju wyjeżdża więcej Polaków niż przyjeżdża do Polski cudzoziemców. W $2010 \mathrm{r}$. GUS oszacował, że za granicą czasowo przebywało 1,99 mln osób. Najwyższy poziom emigracji z Polski został osiagnięty w 2007 r. i wyniósł 2,3 mln osób ${ }^{20}$.

W latach 2010-2011 dla wielu Polaków wyjazd za granicę w poszukiwaniu pracy był ostatecznością, a decyzja o wyjeździe była najczęściej podyktowana brakiem możliwości znalezienia pracy w kraju. Od lat dwutysięcznych głównym powodem wyjazdu Polaków za granicę są względy ekonomiczne. Z danych Komitetu Integracji Europejskiej wynika, że dla ponad 50\% wyjeżdżających głównym motywem jest podjęcie oferty pracy, a dla następnych $42 \%$ - jest to poszukiwanie pracy i chęć zarobku ${ }^{21}$.

W przypadku najnowszej emigracji mamy do czynienia z dwoma głównymi grupami emigrantów. Pierwszą grupę stanowią osoby słabo wykształcone, które nie mają szans na znalezienie jakiegokolwiek zatrudnienia w miejscu zamieszkania i dlatego skłonne są do emigracji i podjęcia tam każdej pracy. Druga grupa to osoby dobrze wykształcone, które w pracy za granicą widzą szansę na spełnienie swoich aspiracji ekonomicznych oraz lepsze wykorzystanie swoich umiejętności i kwalifikacji.

Typowy polski emigrant jest relatywnie młody. Ponad 70\% polskich emigrantów jest, bowiem w wieku 18-34 lat. Dane brytyjskie zbierane w ramach systemu WRS pokazały, iż ponad $80 \%$ Polaków, którzy przybyli do Wielkiej Brytanii po 1 maja 2004 roku mieściło się w kategorii wiekowej 18-34 lat ${ }^{22}$.

Tak znaczący odpływ młodej części populacji z Polski jest istotnym uszczerbkiem w kapitale ludzkim. Tym większym, że często ma charakter drenażu mózgów. Dodatkowo negatywnym dla Polski skutkiem emigracji młodych Polaków jest zwiększanie populacji krajów docelowych. I tak w Wielkiej Brytanii od 2004 r. przyszło na świat

19 A. Gwiazda, Migracje, a tempo wzrostu gospodarczego, w: Procesy migracyjne w kontekście przemian kulturowo-cywilizacyjnych, red. E. Polak, J. Leska-Ślęzak, Pelplin 2007, s. 19.

${ }^{20}$ Podstawowe informacje o sytuacji demograficznej Polski w $2011 \mathrm{r}$., op. cit.

21 Powody wyjazdu Polaków do Wielkiej Brytanii, Urząd Komitetu Integracji Europejskiej. Cyt. za: A. Gwiazda, Demograficzne wyzwania, op. cit. s. 107.

22 Podstawowe informacje o sytuacji demograficznej, GUS, op. cit. 
ponad 77000 polskich dzieci²3. Tylko w roku 2010 liczba ta wynosiła blisko 20000 . Tak wysoka liczba urodzeń oceniana jest przez specjalistów, jako element migracji osiedleńczej, co oznacza, że wiele z polskich emigrantów planuje osiedlić się na stałe w kraju goszczącym ${ }^{24}$.

Obserwowane od lat dziewięćdziesiątych zmiany demograficzne zachodzące w Polsce niestety nie nastrajają pozytywnie. Utrzymująca się od lat spadkowa tendencja liczby urodzeń przełoży się w przyszłości na niską dzietność, co w konsekwencji może wywołać poważny niż demograficzny, zagrażający podstawom rozwojowym naszego państwa. Dodatkowym elementem, który wzmacnia te i tak złe prognozy jest wysoki poziom emigracji, a zwłaszcza emigracji ludzi młodych i zbyt niski poziom imigracji.

Kolejny czynnik to wydłużanie się trwania życia. Jakkolwiek jest to bardzo pozytywne zjawisko, to w zestawieniu z dwoma wcześniej wymienionymi w perspektywie 40-50 lat przyniesie bardzo niekorzystne zmiany w postaci ograniczenia podaży siły roboczej na rynku pracy oraz wzrostu osób starszych w społeczeństwie. W gospodarce będą generowane zdecydowanie wyższe koszty niż dochody, co zaowocuje spadkiem tempa wzrostu gospodarczego i spowoduje jeszcze wolniejszy rozwój kraju. Ponadto większa liczba emerytów niż osób pracujących w społeczeństwie doprowadzi do całkowitego załamania się systemu emerytalnego.

Biorąc pod uwagę zagrożenia wynikające ze zmian demograficznych, którym podlega społeczeństwo polskie należałoby jak najszybciej wdrożyć także rozwiązania, które zwiększą liczbę osób dostępnych na rynku pracy. Wydłużenie wieku emerytalnego do 67 roku życia, które stało się już faktem, to tylko pierwszy krok. Trzeba zmienić politykę imigracyjną w celu ułatwienia osiedlania się i podejmowania legalnej pracy w Polsce przez obcokrajowców, którzy będą konieczni żeby ustabilizować rynek pracy. Jak pisze Adam Gwiazda: „...w ciagu najbliższych dwóch dekad powinniśmy przyjąć 2-3 mln imigrantów i to bez obaw, że odbiorą nam pracę. Imigranci uzupełnią jedynie polski rynek" ${ }^{, 25}$.

Trzeba zadbać o zwiększenie aktywności zawodowej osób w wieku produkcyjnym. W Polsce wskaźnik zatrudniania w 2011 r. wynosił tylko 59,2\%. Dla porównania w Szwajcarii wynosił 79,5\%. Szczególnie do większej mobilności trzeba aktywować grupę osób w wieku 50+ oraz poprawić warunki do pracy i życia ludziom młodym.

Dotychczasowa polityka, zarówno gospodarcza, jak i społeczna (wysokie podatki, niskie pensje, brak dostępu do tanich mieszkań) powoduje, że praca w kraju, szczególnie z perspektywy ludzi młodych staje się nieopłacalna. Dodatkowo brak długofalowej, przyjaznej polityki rodzinnej powoduje, że młode Polki wolą, żeby ich dzieci przychodziły na świat w innych niż Polska, odznaczających się wyższym poziomem bezpieczeństwa socjalnego i ekonomicznego krajach.

Brak rozwagi w podejmowaniu decyzji mogących zmienić niekorzystny dla Polski trend starzenia się ludności i jego stopniowego wyludniania doprowadzi w perspektywie nawet 50 lat do poważnych konsekwencji zagrażających bezpieczeństwu państwa.

23 Sytuacja demograficzna Polski, Rzqdowa Rada Ludnościowa. Raport 2010-2011, Warszawa 2011, s. 161

24 Por.: D. Pszczółkowska, Jakjuż rodzić to na wyspach, „Gazeta Wyborcza”, 11.03.2011, s. 12.

25 A. Gwiazda, Demograficzne wyzwania, op. cit., s. 119. 
Przeciwdziałanie zbliżającej się katastrofie demograficznej powinno stanowić priorytetowy kierunek w działaniach państwa obejmujący kompleks przedsięwzięć w dziedzinie ekonomicznej, społecznej, kulturowej i edukacyjnej.

\title{
STRESZCZENIE
}

W drugiej połowie XX wieku kiedy wzrosło natężenie współzależności w stosunkach międzynarodowych i przyspieszyły procesy globalizacji, bezpieczeństwo przestało być utożsamiane wyłącznie z wymiarem polityczno-militarnym. Równie ważne dla bezpieczeństwa okazały się inne sfery działalności państwa, jak gospodarka, ekologia, kultura czy społeczeństwo. W każdej z tych dziedzin pojawiają się problemy, które mogą zagrozić bezpieczeństwu państwa. W Polsce jednym $\mathrm{z}$ takich problemów są bardzo niekorzystne zmiany demograficzne zachodzące w polskim społeczeństwie. Ich negatywne skutki są odczuwalne już obecnie, a w miarę upływu czasu będą się nasilały. Już za około 20 lat będą odgrywały pierwszoplanową rolę w kształtowaniu bezpieczeństwa Polski, w szczególności zaś jego wymiaru społeczno-ekonomicznego.

\section{SOCIO-ECONOMIC SECURITY OF POLAND IN THE PERSPECTIVE OF DEMOGRAPHIC FACTOR}

\begin{abstract}
In the second half of the XX century, when intensity of coexistence in international relations increased and globalizing processes accelerated, security stopped being identified with political and military dimension only. Other spheres of state's activity as: economy, ecology, culture or society, emerged to be as much important for national security as problems which appear in the mentioned spheres may threaten it. In Poland, disadvatageous demographic changes which are taking place in the society, are one of such problems. It is claimed that fatal effects will be observed in 20 years and they will be forming national security of the country, especially its economic and social aspect.
\end{abstract}

